\title{
Analisis Variasi Temperatur Nitridasi Plasma terhadap Kekerasan, Keausan dan Struktur Mikro Baja AISI 4340 pada Poros Transmisi
}

\author{
Akza Arif ${ }^{1, a)}$, Pathya Rupajati ${ }^{2, b)}$ dan Dwita Suastiyanti ${ }^{3, c)}$ \\ 1,2,3) Program Studi Teknik Mesin ITI, \\ J1. Raya Puspiptek Serpong, Tanggerang Selatan-Banten, Indonesia, 15320 \\ a)akzaarif@gmail.com, ${ }^{\text {b) }}$ pathya.rupajati@iti.ac.id, ${ }^{c}$ dwita_suastiyanti@iti.ac.id
}

\begin{abstract}
Abstrak
Baja paduan rendah AISI 4340 banyak digunakan sebagai bahan komponen mesin seperti pada poros transmisi yang pada pemakaiannya banyak mengalami gesekan atau aus. Guna meningkatkan ketahanan aus pada suatu bahan material, diperlukan perlakuan pengerasan permukaan salah satunya yaitu nitridasi plasma. Nitridasi plasma adalah pelapisan permukaan bahan dengan gas nitrogen dengan membentuk lapisan nitrida yang keras pada permukaan bahan. Pada penelitian ini, dilakukan proses nitridasi plasma dengan variasi temperatur $300^{\circ} \mathrm{C}, 350^{\circ} \mathrm{C}, 400^{\circ} \mathrm{C}$ dan $450^{\circ} \mathrm{C}$ serta waktu tetap 4 jam dan tekanan nitrogen tetap 1,6 mBar. Tujuan penelitian ini adalah untuk mengetahui pengaruh temperatur proses terhadap kekerasan, keausan dan struktur mikro dari material AISI 4340 nitridasi plasma. Hasil uji kekerasan diperoleh nilai kekerasan terbesar pada temperatur $350^{\circ} \mathrm{C}$ adalah $304,1 \mathrm{HVN}$. Hasil dari uji keausan diperoleh laju keausan terendah pada temperatur $350^{\circ} \mathrm{C}$ adalah $2,63 \times 10^{-6} \mathrm{~mm}^{2} / \mathrm{kg}$. Sedangkan hasil uji struktur mikro menunjukkan adanya lapisan nitrida besi yang sangat tipis dimana terdeposisikan pada permukaan baja AISI 4340 yang dapat meningkatkan kekerasan dan keausan.
\end{abstract}

Kata kunci: nitridasi plasma, temperatur, kekerasan, baja AISI 4340

\begin{abstract}
Low alloy steel AISI 4340 has been used as a material for machine component such as transmussion shafts which in use they suffered a lot of friction or wear. To increase wear resistance to a material, a surface hardening treatment is needed, one of which is plasma nitriding. Plasma nitriding is a surface treatment of material with nitrogen gasses to nitride plate hard on surface. At this study, procces plasma nitriding with varios temperature of $300^{\circ} \mathrm{C}, 350^{\circ} \mathrm{C}, 400^{\circ} \mathrm{C}$ dan $450^{\circ} \mathrm{C}$ and fixed duration process of 4 hours and fixed nitrogen pressure of 1,6 mBar. The purpose of this study is to determine the effect of temperature process in to hardness, wear rate and microstructure of AISI 4340 steel plasma nitriding. The results of the hardness test obtained, the greatest hardness at a temperature of $350^{\circ} \mathrm{C}$ is $304,1 \mathrm{HVN}$. The results of wear test obtained, the lowest wear rate at a temperature of $350^{\circ} \mathrm{C}$ is $2,63 \times 10^{-6} \mathrm{~mm}^{2} / \mathrm{kg}$. While the micro structure test results show that there is a very thin white layer which can be deposited on the surface of AISI 4340 steel which can increase hardness and wear.
\end{abstract}

Keywords: plasma nitriding, temperature, hardness, AISI 4340 steel

\section{PENDAHULUAN}

Pengembangan dan inovasi untuk kemajuan teknologi permesinan berbanding lurus dengan kebutuhan. Salah satu bagian pada mesin yang sering mengalami kegagalan dalam operasi adalah poros, karena poros mengalami pembebanan yang terus berulang. Poros transmisi pada umumnya dibuat dari baja paduan rendah (low alloy steel). Salah satunya baja AISI 4340, untuk mencegah kegagalan poros dilakukan perlakuan permukaan guna mendapatkan kekerasan dan tahan aus yang optimal pada poros [1].

Dalam industri otomotif, komponen-komponen mesin yang paling utama untuk dilakukan proses perlakuan permukaan (surface treatment) untuk meningkatkan kekerasan dan ketahan aus (wear resistance) yang lebih baik pada bagian-bagian yang bergerak dan saling bergesekan satu dengan lainnya. Teknik modifikasi permukaan menggunakan plasma menawarkan fleksibilitas yang besar dan yang mampu menyesuaikan sifat-sifat kimia dan struktur permukaan yang diinginkan dan tidak tergantung pada sifat dasarnya [2].

Surface treatment didefinisikan sebagai usaha meningkatkan kualitas permukaan suatu material/komponen sesuai yang diinginkan. Cara untuk meningkatkan kualitas permukaan pada dasarnya dapat ditempuh dengan menambahkan unsur lain, salah satunya yaitu nitrogen yang disebut dengan nitridasi plasma. Perlakuan permukaan dengan menambahkan unsur lain terbagi menjadi dua cara yaitu konvensional dan modern, cara konvensional seperti nitridasi, karburasi dan karbonitridasi sedangkan cara modern adalah teknik laser, implantasi ion dan plasma lucutan pijar [3].

Nitridasi plasma ini adalah metode pengerasan permukaan memanfaatkan teknologi lucutan pijar (glow 
discharge technology) untuk memasukkan unsur nitrogen ke permukaan diikuti dengan proses difusi ke dalam material.

Lapisan nitrida besi ini yang dapat meningkatkan kekerasan, ketahanan aus dan korosi sehingga dapat meningkatkan umur pakai. Nitridasi plasma efektif pada baja paduan karena tingkat kecepatan (waktu yang dibutuhkan lebih cepat dan suhu nitridasi relatif lebih rendah), tidak memerlukan quenching sehingga mengurangi distorsi, efisiensi pemakaian gas, energi listrik, dan tidak menimbulkan polusi [4].

Pada penelitian ini dilakukan analisis nitridasi plasma dengan variasi temperatur $\left(300^{\circ} \mathrm{C}, 350^{\circ} \mathrm{C}, 400^{\circ} \mathrm{C}\right.$ dan $450^{\circ} \mathrm{C}$ ) terhadap kekerasan, kausan dan struktur mikro baja AISI 4340 pada poros transmisi. Uji kekerasan dilakukan dengan metode vickers pada material tanpa nitridasi dan yang telah nitridasi guna menganilasa efek dari nitridasi. Uji ketahanan aus dilakukan menggunakan alat uji keausan Ogoshi. Pengamatan struktur mikro dilakukan dengan mikroskop optik guna melihat pembentukan lapisan pada permukaan material yang dinitridasi.

\section{LANDASAN TEORI}

\section{A. Baja AISI 4340}

AISI 4340 mempunyai arti yaitu AISI adalah standar Amerika Serikat yang merupakan singkatan dari American Iron and Steel Institute, sedangkan arti dari 4340 adalah dua (2) digit pertama yaitu 43 menunjukan baja paduan Nickel (Ni), Chromium (Cr) dan Molybdenum (Mo), sedangkan dua (2) digit selanjutnya yaitu 40 menunjukan kandungan karbon pada material tersebut yaitu $0,4 \%$ [5]. Kandungan unsur yang terdapat dalam baja AISI 4340 ditunjukkan pada Tabel 1.

Tabel 1. Komposisi Baja AISI 4340

\begin{tabular}{cc}
\hline Komposisi Kimia & $\begin{array}{c}\text { Spesifikasi Baja } \\
\text { AISI 4340 }\end{array}$ \\
\hline C (\%) & $0,38-0,43$ \\
Si (\%) & $0,20-0,35$ \\
Mn (\%) & $0,60-0,80$ \\
P (\%) & 0,03 \\
S (\%) & 0,04 \\
Ni (\%) & $1,65-2$ \\
Cr (\%) & $0,70-0,90$ \\
Mo (\%) & $0,20-0,30$ \\
\hline
\end{tabular}

Sedangkan untuk sifat mekanik material baja AISI 4340 ditunjukan seperti pada Tabel 2.

Tabel 2. Sifat Mekanik Baja AISI 4340

\begin{tabular}{cc}
\hline Properties & Metric \\
\hline Hardness, Brinell & 217 \\
Hardness, Rockwell (converted from & 95 \\
Brinell) & 228 \\
Hardness, Vickers (converted from Brinell) & $745 \mathrm{MPa}$ \\
Tensile strength & $470 \mathrm{MPa}$ \\
Yield strength & $190-210 \mathrm{GPa}$ \\
Elastic modulus &
\end{tabular}

\section{B. Nitridasi Plasma}

Nitridasi plasma adalah pelapisan permukaan spesimen dengan gas nitrogen berbentuk plasma untuk membentuk fase nitrida yang keras pada permukaan spesimen. Skema peralatan ditunjukkan secara garis besar pada Gambar 1 dengan komponen utama berupa: tabung nitridasi, sistem vakum, sistem pemanas, sistem tegangan tinggi, tangki beserta sistem aliran gas, dan sistem pemegang material. Gas nitrogen dari tabung dialirkan ke tabung nitridasi yang telah divakumkan dan dipanaskan sehingga membentuk plasma. Spesimen yang dikeraskan berada di pemegang material sebagai katoda dan plasma ditarikdan dipercepat ke sampel oleh pengaruh medan listrik menggunakan tegangan tinggi sehingga terjadi pengerasan permukaan [6].

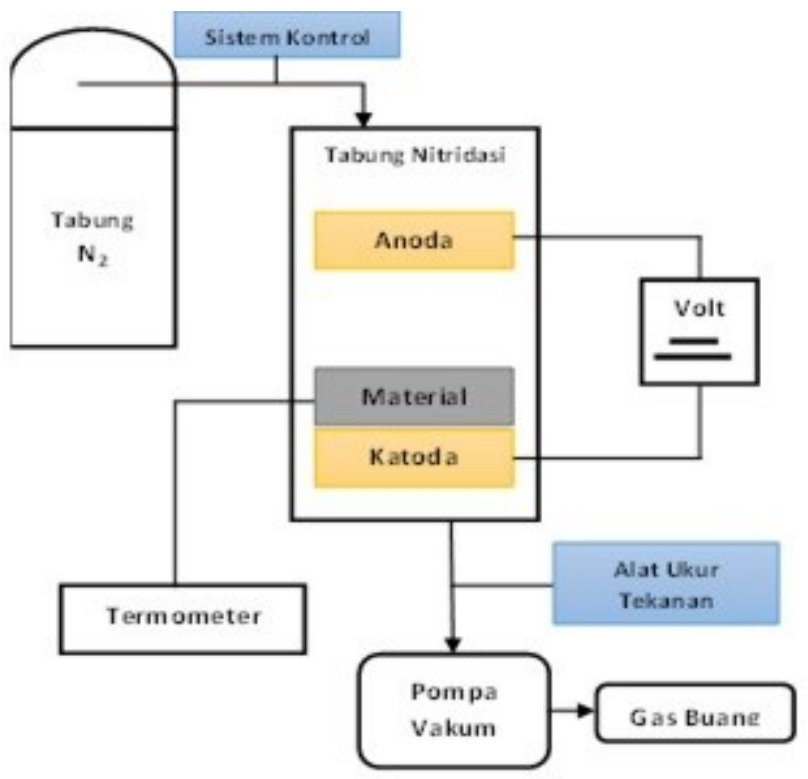

Gambar 1. Skema Proses Nitridasi Plasma

Ruang nitridasi merupakan bagian utama yang berfungsi sebagai wadah untuk proses nitridasi dimana plasma nitrogen berdifusi ke dalam permukaan spesimen. Aliran gas bisa berupa gas tunggal $\mathrm{N}_{2}$, bisa pula berupa campuran gas misalkan $\mathrm{N}_{2} / \mathrm{H}_{2}$. Tekanan di dalam tabung nitridasi, dengan mempergunakan pompa vakum, dijaga pada $10^{-3}$ Bar. Vakum yang baik akan menentukan hasil yang lebih bersih mengingat kontaminasi oleh sisa oksigen, misalnya, bisa memberikan campuran lapisan nitrida dan oksida pada lapisan permukaan yang dikeraskan. Suhu operasi yang optimal perlu ditentukan untuk setiap aplikasi yang berbeda. Pada suhu lebih tinggi, lapisan keras yang dihasilkan bisa lebih dalam namun dengan resiko terjadi perubahan dimensi dan penurunan kekerasan maksimum yang bisa dicapai.

Proses nitridasi dilakukan dengan mendeposisikan ion nitrogen pada permukaan yang dikeraskan. Untuk membentuk ion nitrogen dilakukan dengan cara memplasmakan gas nitrogen di dalam tabung reaktor plasma sehingga terbentuk pasangan ion nitrogen dan elektron. Untuk memplasmakan ini digunakan tegangan 
tinggi DC dengan polaritas positif pada anoda dan polaritas negatif pada katoda sehingga terjadi lucutan pijar dan terbentuk plasma.

Pada proses nitridasi, spesimen ditempatkan pada katoda sehingga ion-ion nitrogen yang terbentuk terdeposisi pada permukaan spesimen. Ion-ion nitrogen yang terdeposisi pada permukaan selanjutnya berdifusi dan larut secara interstisi membentuk lapisan nitrida. Jika yang dinitridasi adalah baja dengan unsur utama Fe maka akan terbentuk lapisan nitrida besi $(\mathrm{FeN})$ pada permukaan. Nitrida besi (FeN) mempunyai sifat sangat keras sehingga membentuk lapisan keras pada permukaan baja yang dinitridasi. Nitridasi Plasma yang dilakukan memenuhi parameter yang ditunjukkan pada Tabel 3 .

Tabel 3. Parameter Nitridasi Plasma

\begin{tabular}{|c|c|c|c|c|}
\hline Metode & $\begin{array}{c}\text { Kode } \\
\text { Spesimen }\end{array}$ & $\begin{array}{c}\text { Temperatur } \\
\left({ }^{\circ} \mathrm{C}\right)\end{array}$ & $\begin{array}{l}\text { Waktu } \\
\text { (Jam) }\end{array}$ & $\begin{array}{c}\text { Tekanan } \\
\text { (mbar) }\end{array}$ \\
\hline \multirow{5}{*}{ Nitridasi } & $\mathrm{A}$ & 300 & \multirow[t]{4}{*}{7} & \multirow{4}{*}{1,6} \\
\hline & B & 350 & & \\
\hline & $\mathrm{C}$ & 400 & & \\
\hline & $\mathrm{D}$ & 450 & & \\
\hline & RAW & $\mathrm{Ta}$ & a Nitridas & \\
\hline
\end{tabular}

\section{Pengujian Kekerasan Vickers}

Uji kekerasan vickers menggunakan indentor piramida intan yang pada dasarnya berbentuk bujursangkar. Angka kekerasan vickers. Didefinisikan sebagai beban dibagi dengan luas permukaan lekukan. VHN ditentukan oleh persamaan (1):

$\mathrm{HVN}=\frac{1,854 x \mathrm{P}}{d^{2}}$

Dimana:

$\mathrm{P}=$ beban yang digunakan $(\mathrm{kg})$

$\mathrm{d}=$ panjang diagonal rata-rata $(\mathrm{mm})$

\section{Pengujian Keausan}

Keausan dapat didefinisikan sebagai lepasnya atom dari permukaan material dan pengurangan sebagai akibat dari aksi mekanik atau dapat didefinisikan sebagai bagian yang hilang dari permukaan yang padat. Keausan terjadi apabila dua buah benda yang saling menekan dan saling bergesekan. Keausan yang lebih besar terjadi pada bahan yang lebih lunak. Pengujian ketahanan aus diperoleh dengan metode Ogoshi dan dinyatakan dalam persamaan (2):

$W_{S}=\frac{B \cdot b^{3}}{8 \cdot r \cdot P_{o} \cdot l_{o}}$

Dimana :

$\mathrm{Ws}=$ Keausan spesifk $\left(\mathrm{mm}^{2} / \mathrm{kg}\right)$

$\mathrm{B}=$ Lebar disk (piringan) pengaus $(\mathrm{mm})$

$\mathrm{b}^{3}=$ Lebar keausan pada benda uji $(\mathrm{mm})$

$\mathrm{r} \quad=$ Radius piringan pengaus $(\mathrm{mm})$

$\mathrm{P}_{\mathrm{o}}=$ Beban tekan pada saat pengausan $(\mathrm{kg})$

$\mathrm{I}_{\mathrm{o}}=$ Jarak tempuh dari proses pengausan $(\mathrm{mm})$

\section{E. Pengujian Struktur Mikro}

Pengamatan struktur mikro adalah pengujian untuk mengetahui susunan struktur logam pada suatu benda uji atau spesimen dengan pembesaran tertentu. Struktur mikro dan sifat paduannya dapat diamati dengan berbagai cara tergantung pada sifat yang dibutuhkan. Salah satu cara dalam mengamati struktur suatu bahan yaitu dengan teknik metallographic (pengujian mikroskop optik).

Proses terjadinya perubahan warna, besar butir, bentuk dan ukuran butir yang mendasari penentuan dari jenis dan sifat fasa pada hasil pengamatan foto struktur mikro adalah diakibatkan adanya proeses pengetsaan. Standar uji yang digunakan dalam pengujian ini adalah ASTM E8 (Standar Practice for Preparation of Metallografi Specimen).

\section{METODE PENELITIAN}

Penelitian dimulai dengan persiapan material dan peralatan laboratorium yang diperlukan yang diikuti dengan tahap-tahap selanjutnya mengacu pada diagram alir seperti ditunjukkan pada Gambar 2.

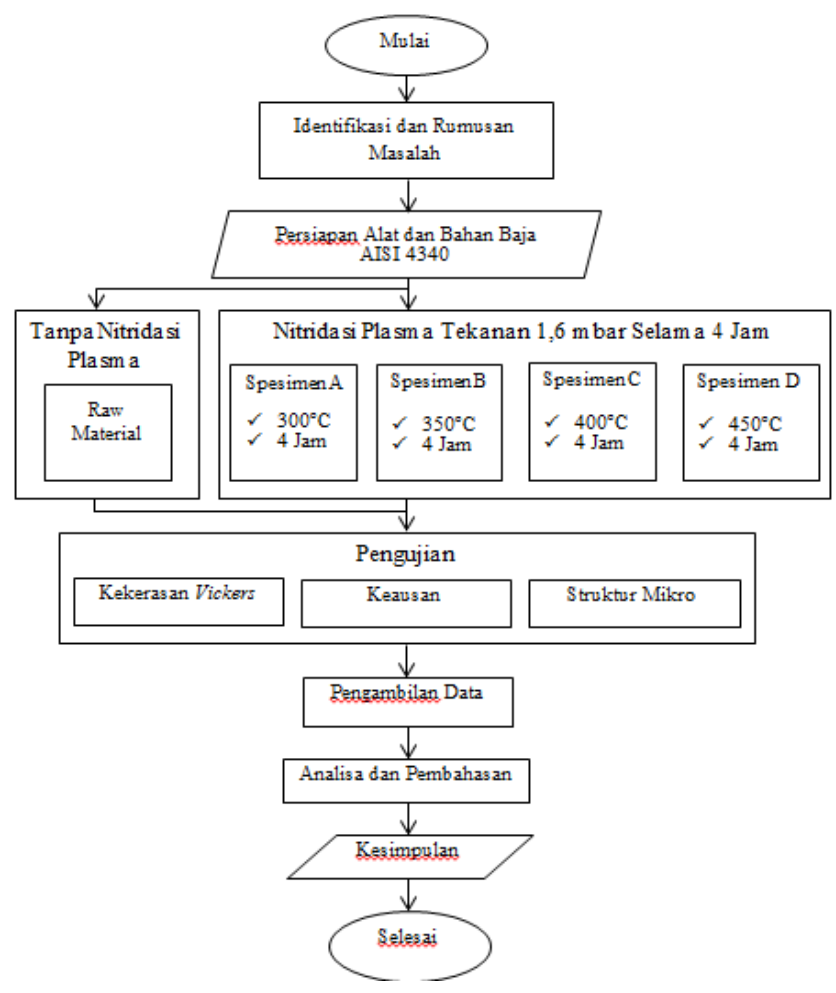

Gambar 2. Diagram Alir Penelitian

Spesimen untuk proses nitridasi plasma adalah 5 buah baja AISI 4340 dengan dimensi diameter $25 \mathrm{~mm}$, tebal 5 $\mathrm{mm}$. Dimensi spesimen seperti ditunjukkan pada Gambar 3.

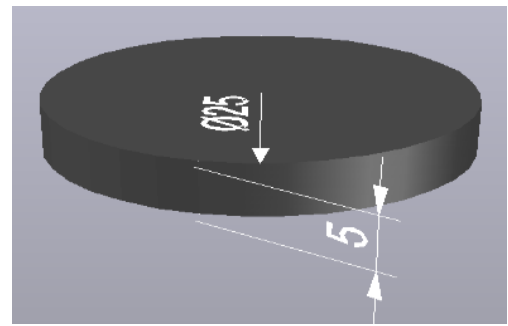

Gambar 3. Dimensi Spesimen AISI 4340 (mm) 
Pengerasan permukaan metode nitridasi plasma dilakukan pada tekanan gas nitrogen 1,6 mbar [7] dengan variasi temperatur $300^{\circ} \mathrm{C}, 350^{\circ} \mathrm{C}, 400^{\circ} \mathrm{C}$ dan $450^{\circ} \mathrm{C}$ selama 4 jam [8], pengujian sifat mekanis, yaitu pengujian kekerasan vickers, pengujian keausan dan struktur mikro.

\section{HASIL DAN PEMBAHASAN}

\section{A. Hasil Pengujian Kekerasan Vickers}

Pada pengujian kekerasan vickers menggunakan 10 titik sampel, beban indentasi sebesar 10 gf, jarak $150 \mu \mathrm{m}$ dan waktu pembebanan 5 detik. Pengukuran ini dimulai dari sisi terluar dengan jarak $3 \mathrm{~mm}$ kemudian jarak antara titik 2 dengan titik-titik berikutnya masing-masing $2 \mathrm{~mm}$ seperti ditunjukkan pada Gambar 4.

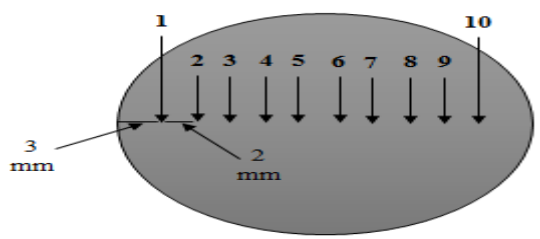

Gambar 4. Titik-titik Spesimen Pengujian Kekerasan

Nilai kekerasan setelah dinitridasi dengan variasi suhu $300^{\circ} \mathrm{C}, 350^{\circ} \mathrm{C}, 400^{\circ} \mathrm{C}$ dan $450^{\circ} \mathrm{C}$ pada tekanan 1,6 mbar serta waktu 4 jam angka kekerasannya mengalami peningkatan yang bervariasi. Hasil rata-rata kekerasan untuk spesimen sebelum dan sesudah dilakukan metode nitridasi plasma ditunjukkan pada Tabel 4.

Tabel 4. Rata-rata Kekerasan Sebelum dan Sesudah Nitridasi Plasma

\begin{tabular}{ccc}
\hline Spesimen & $\begin{array}{c}\text { Temperatur } \\
\left.\mathbf{(}^{\mathbf{O}} \mathbf{C}\right)\end{array}$ & $\begin{array}{c}\text { Rata-rata } \\
\text { Kekerasan } \\
(\mathbf{H V N})\end{array}$ \\
\hline Tanpa & - & 207,3 \\
Nitridasi & 300 & 273,8 \\
A & 350 & 304,1 \\
B & 400 & 241,6 \\
C & 450 & 221,7 \\
D & & \\
\hline
\end{tabular}

Berdasarkan data Tabel 4 untuk memudahkan pembacaan pola nilai kekerasannya maka dibuat grafik hubungan antara nilai kekerasan pada spesimen baja AISI 4340 sebelum dan sesudah nitridasi plasma dengan perubahan temperatur dan ditunjukkan pada Gambar 5.

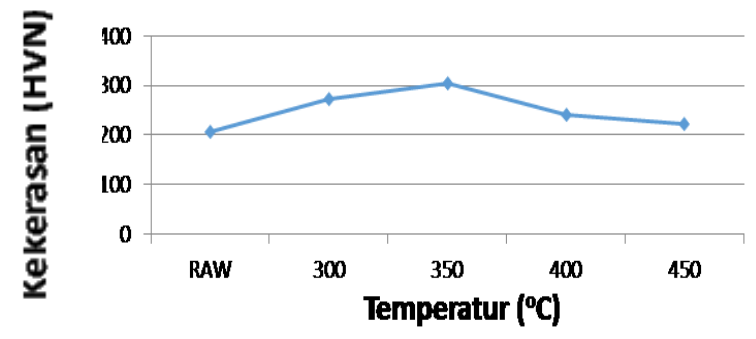

Gambar 5. Grafik Hubungan Nilai Kekerasan Terhadap Perubahan Temperatur

Pada Gambar 5 dapat dilihat hasil kekerasan yang berbeda pada saat sebelum dan sesudah proses nitridisasi. Sebelum proses nitridisasi kekerasan rata - rata spesimen adalah 207,3 HVN, sesudah proses nitridisasi terjadi peningkatan kekerasan sampai pada temperatur $350^{\circ} \mathrm{C}$ dikarenakan terbentuknya lapisan white layer.

Pada temperatur $300^{\circ} \mathrm{C}$ tekanan 1.6 mbar waktu 4 jam kekerasan meningkat menjadi 273,8 HVN kemudian meningkat pada temperatur $350^{\circ} \mathrm{C}$ menjadi $304,1 \mathrm{HVN}$. Pada temperatur $400^{\circ} \mathrm{C}-450^{\circ} \mathrm{C}$ kekerasannya cenderung menurun menjadi 241,6 HVN dan 221,7 HVN. Pada temperatur $400^{\circ} \mathrm{C}-450{ }^{\circ} \mathrm{C}$ terjadi pembentukkan white layer semakin tebal dengan baik tetapi kekerasan permukaannya menurun seiring bertambahnya temperatur pemanasan. Hal tersebut disebabkan karena temperatur mencapai batas yang sangat maksimal atau titik jenuh pada proses nitridasi untuk baja AISI 4340 tersebut.

Kekerasan rata-rata terbesar diperoleh pada temperatur $350^{\circ} \mathrm{C}$. Hal ini disebabkan pada temperatur tersebut tidak hanya terbentuk pasangan kekosongan dan sisipan tetapi juga terbentuk fasa kedua $\left(\mathrm{Fe}_{2} \mathrm{~N}\right)$. Hal ini memberi kontribusi yang cukup besar terhadap sifat kekerasan permukaan material, di atas temperatur $350^{\circ} \mathrm{C}$ ternyata kekerasannya menurun. Dikarenakan material tersebut sudah jenuh sehingga dengan kenaikan temperatur yang lebih lanjut justru tidak ada artinya tapi akan menurunkan kekerasannya [9].

\section{B. Hasil Pengujian Keausan}

Pada pengujian keausan menggunakan parameter kecepatan 1,97 m/s dan diberikan beban 3,16 kg dengan jarak tempuh gesekan $100 \mathrm{~m}$, diameter cincin $30 \mathrm{~mm}$ dengan ketebalan $3 \mathrm{~mm}$. Dengan metode Ogoshi semakin lebar jejak keausan yang didapat maka nilai keausan spesifik semakin bertambah besar. Prinsip kerja dari pengujian tersebut adalah dengan cara menggesekan material dengan disk dengan parameter tertentu sehingga terjadi keausan lelah pada material yang diuji seperti yang ditunjukkan pada Gambar 6 .

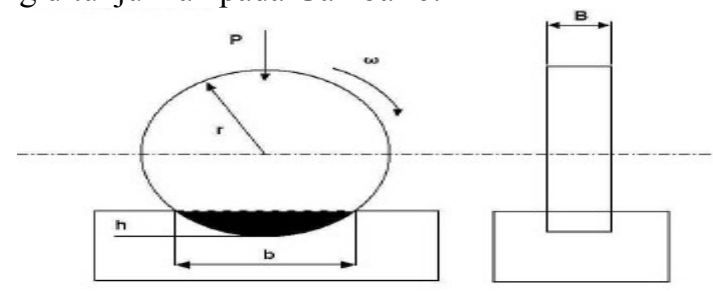

Gambar 6. Prinsip Kerja Pengujian Keausan 
Hasil uji keausan ditunjukkan pada Tabel 5.

Tabel 5. Keausan Spesifik Spesimen Baja AISI 4340

\begin{tabular}{ccc}
\hline Spesimen & $\begin{array}{c}\text { Temperatur } \\
\left({ }^{\circ} \mathbf{C}\right)\end{array}$ & $\begin{array}{c}\text { Keausan Spesifik } \\
\left(\mathbf{m m}^{\mathbf{2}} \mathbf{/ k g}\right)\end{array}$ \\
\hline Tanpa Nitridasi & - & $3,24 \times 10^{-6}$ \\
A & 300 & $2,82 \times 10^{-6}$ \\
B & 350 & $2,63 \times 10^{-6}$ \\
C & 400 & $2,92 \times 10^{-6}$ \\
D & 450 & $3,03 \times 10^{-6}$ \\
\hline
\end{tabular}

Berdasarkan data Tabel 5 untuk memudahkan pembacaan pola nilai keausan spesifik maka dibuat grafik hubungan antara nilai keausan spesifik pada spesimen baja AISI sbelum dan sesudah nitridasi plasma dengan an temperatur dan disajikan pada Gambar 7.

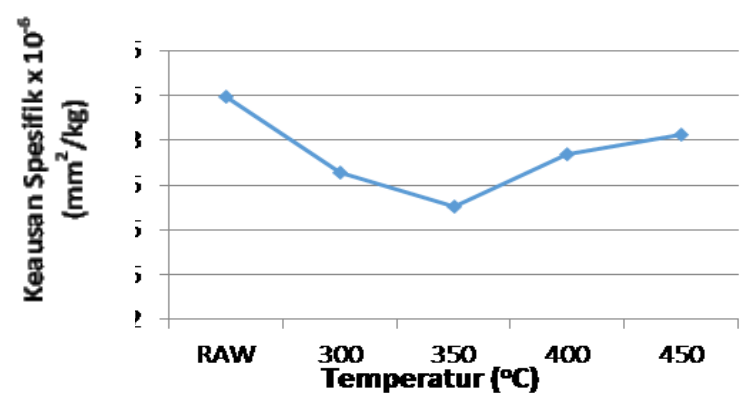

Gambar 7. Grafik Hubungan Keausan Spesifik Terhadap Perubahan Temperatur

Hasil nilai keausan spesifik yang terendah terdapat pada temperatur nitridasi $350^{\circ} \mathrm{C}$ dengan laju keausan sebesar 2,63 x $10^{-6} \mathrm{~mm}^{2} / \mathrm{kg}$. Dapat diketahui bahwa spesimen baja AISI 4340 hasil nitridasi plasma memiliki ketahanan terhadap keausan sebanding dengan peningkatan kekerasan pada permukaannya sampai pada temperatur $350^{\circ} \mathrm{C}$. Pada temperatur diatas $350^{\circ} \mathrm{C}$ cenderung menurun sifat tahan aus sesuai dengan kenaikan nilai keausan spesifiknya. Hal ini dikarenakan telah mencapai batas temperatur yang sangat maksimal atau titik jenuh pada proses nitriding untuk baja AISI 4340 tersebut [10].

Dengan meningkatnya temperatur nilai keausan spesimen semakin kecil, hal tersebut dikarenakan lapisan white layer yang terbentuk semakin tebal sehingga memiliki sifat yang semakin tahan aus. Semakin kecil nilai keausannya berarti material tersebut mempunyai sifat semakin tahan terhadap keausan atau beban gesekan [11].

\section{Hasil Pengujian Struktur Mikro}

Pengujian struktur mikro dilakukan bertujuan untuk mengetahui struktur mikro pada spesimen baja AISI 4340 , baik pada sampel yang belum mengalami proses nitridasi, maupun yang sudah mengalami proses nitridasi plasma dan mengetahui perubahan yang terjadi. Hasil pengujian struktur mikro untuk baja AISI 4340 sebelum proses nitridasi ditunjukkan pada Gambar 8.

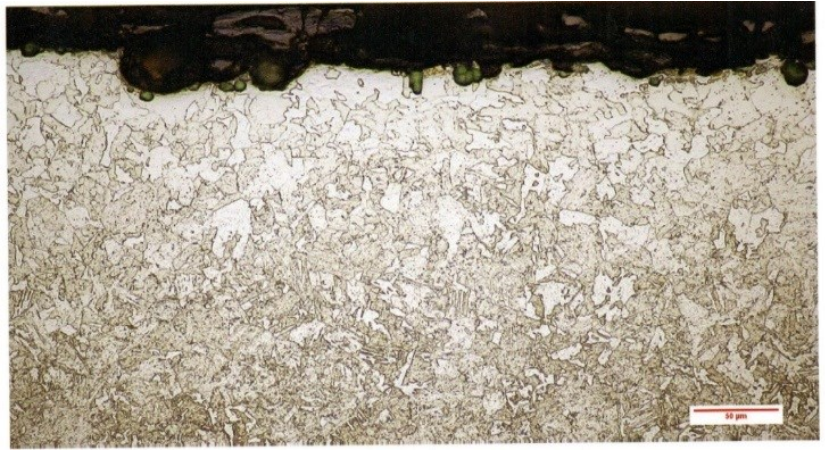

Gambar 8. Struktur Mikro RAW AISI 4340 Sebelum Nitridasi Plasma

Gambar 8 diatas spesimen sebelum proses nitridasi plasma menunjukkan di permukaan raw material tidak terbentuknya lapisan nitrida besi, hal ini menunjukkan bahwa spesimen tanpa nitridasi memiliki nilai kekerasan yang rendah. Spesimen yang sudah dilakukan proses nitridasi plasma dengan variasi temperatur $300^{\circ} \mathrm{C}, 350^{\circ} \mathrm{C}$, $400^{\circ} \mathrm{C}$ dan $450^{\circ} \mathrm{C}$ ditunjukan pada gambar $9-12$.

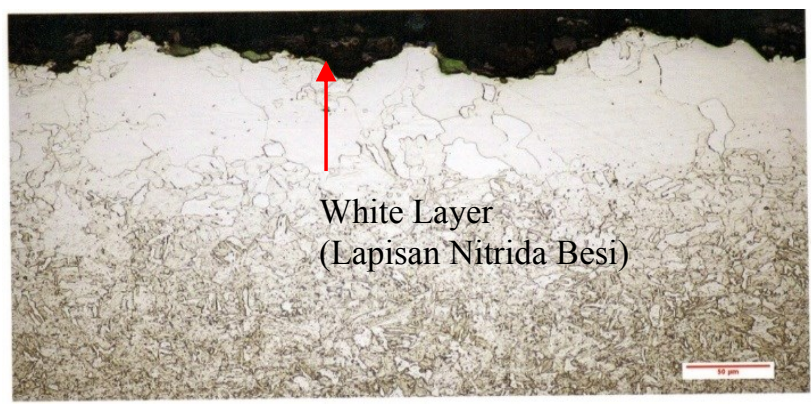

Gambar 9. Struktur Mikro AISI 4340 Nitridasi Plasma $300^{\circ} \mathrm{C}$

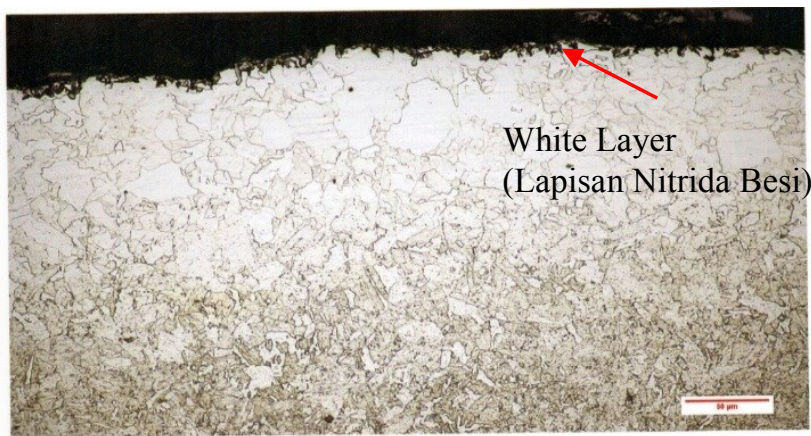

Gambar 10. Struktur Mikro AISI 4340 Nitridasi Plasma $350^{\circ} \mathrm{C}$

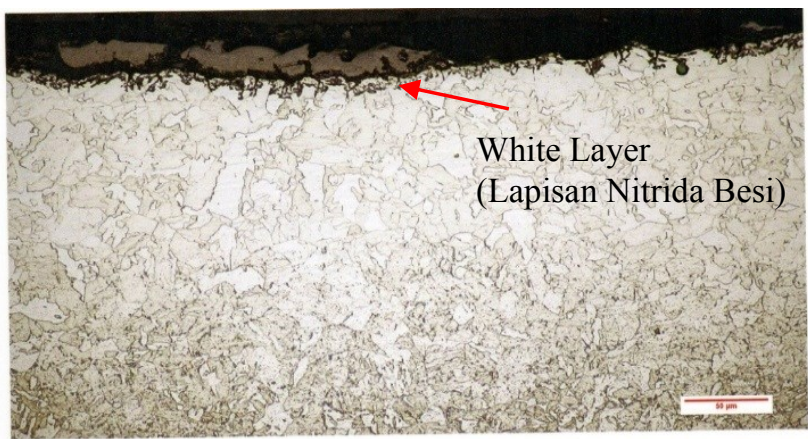


Gambar 11. Struktur Mikro AISI 4340 Nitridasi Plasma $400^{\circ} \mathrm{C}$

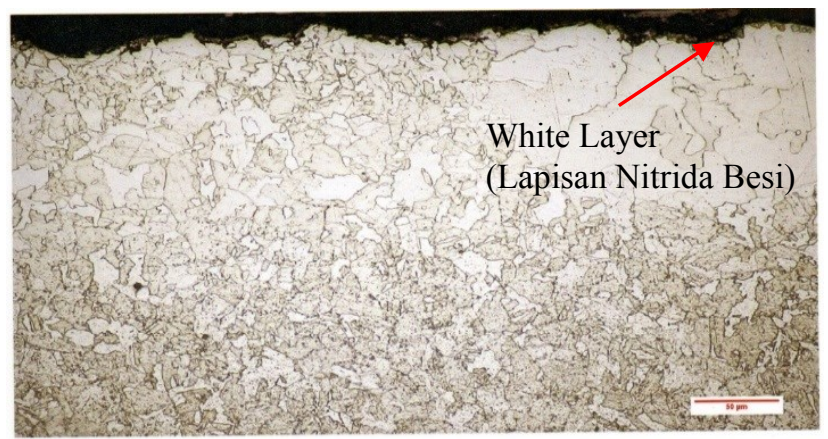

Gambar 12. Struktur Mikro AISI 4340 Nitridasi Plasma $450^{\circ} \mathrm{C}$

Pada spesimen uji yang telah mengalami proses nitridasi, terlihat lapisan nitrida besi cenderung tipis pada permukaan seperti pada Gambar 9-12. Pembentukan lapisan nitrida besi pada permukaan akibat pendifusian unsur nitrogen pada permukaan spesimen uji. Lapisan nitrida besi yang terbentuk memiliki sifat keras dan tahan aus.

Lapisan pada sisi terluar atau disebut white layer, yaitu nitrida yang terbentuk pada permukaan baja akibat dari difusi nitrogen terhadap permukaan baja membentuk lapisan nitrida (FeN). Nitridasi ini dapat terjadi akibat atmosfer pada tungku pemanas yang banyak terdapat atom $(\mathrm{N})$ yang berasal dari ion nitrogen yang terurai. Ion nitrogen akan bereaksi melepaskan atom nitrogen $(\mathrm{N})$ yang akan berdifusi dengan permukaan baja. Atom-atom nitrogen ini akan bereaksi dengan baja (Fe) untuk membentuk lapisan nitrida $\mathrm{Fe}_{2} \mathrm{~N}-\mathrm{Fe}_{3} \mathrm{~N}$ atau $\mathrm{Fe}_{4} \mathrm{~N}$. Lapisan dipermukaan baja membentuk ikatan logam dan non logam sehingga terbentuk ikatan sejenis keramik yang membentuk material komposit yang keras dan mempunyai sifat tahan aus [12].

\section{KESIMPULAN}

Dari hasil penelitian ini dapat diambil beberapa kesimpulan sebagai berikut:

1. Proses nitridasi plasma mempengaruhi bertambahnya sifat kekerasan permukaan baja AISI 4340. Kekerasan terbesar pada temperatur $350^{\circ} \mathrm{C}$ dengan nilai 304,1 HVN. Pada temperatur diatas $350^{\circ} \mathrm{C}$ mengalami penurunan nilai kekerasan dikarenakan temperatur mencapai batas yang sangat maksimal pada proses nitridasi plasma untuk baja AISI 4340.

2. Nilai keausan pada spesimen raw material sebelum nitridasi plasma yaitu sebesar $3,24 \times 10^{-6} \mathrm{~mm}^{2} / \mathrm{kg}$. Sedangkan nilai keausan terendah pada temperatur $350^{\circ} \mathrm{C}$ dengan nilai keausan $2,63 \times 10^{-6} \mathrm{~mm}^{2} / \mathrm{kg}$. Hal tersebut dikarenakan lapisan white layer yang terbentuk semakin tebal sehingga memiliki sifat yang semakin tahan aus. Pada temperatur diatas $350^{\circ} \mathrm{C}$ nilai keausan cenderung naik, hal ini berbanding lurus dengan nilai kekerasan pada spesimen hasil nitridasi plasma.

3. Spesimen raw tidak terbentuk lapisan nitrida (white layer) di permukaan sehingga memiliki nilai kekerasan yang rendah. Sedangkan setelah nitridasi plasma terbentuk lapisan white layer pada permukaan yang memiliki sifat keras dan tahan aus.

\section{UCAPAN TERIMA KASIH}

Ucapan terima kasih disampaikan kepada BATAN Yogyakarta dan CMPFA UI Teknik Metalurgi yang telah memberikan dukungan dalam pengujian/karakterisasi sampel pada penelitian ini.

\section{REFERENSI}

[1] H. Rusjdi, A.W. Pramono, W.B. Faathir, Pengaruh Perlakuan Panas Terhadap Sifat Mekanis dan Struktur Mikro Baja AISI 4340, Jurnal Power Plant, Vol. 4, No. 2, 2016, 92-103.

[2] Sudjatmoko, Wirjoadi, B. Siswanto, Suharni, T. Sujitno, Analisis Struktur Mikro Lapisan Tipis Nitrida Besi yang Ternitridasi pada Permukaan Material Komponen Mesin, Jurnal Iptek Nuklir Ganendra, Vol. 13, No. 2, Juli 2010, 101-111.

[3] T. Sujitno, Aplikasi Plasma dan Teknologi Sputtering Untuk Surface Treatment. Workshop Sputtering Untuk Rekayasa Permukaan Bahan, P3TM-BATAN Yogyakarta, 2003, 1-30.

[4] Sudjatmoko, B. Siswanto, Wirjoadi, \& Lely S.R.M., Pengaruh Nitridasi Ion Suhu Rendah pada Ketahanan Aus dan Korosi Biomaterial Stainless Steel Austenitik 316L, Jurnal Iptek Nuklir Ganendra, Vol. 15, No. 2, Juli 2012, 104-112.

[5] ASM Handbook Vol: 1, Properties and Selection: Irons, Steels, and High-Performance Alloys, ASM International, 1990.

[6] Suprapto, T. Sujitno, Pengerasan Permukaan Baja ST 42 dengan Teknik Nitridasi Ion, Prosiding PPIPDIPTN Puslitbang Teknologi Maju-BATAN Yogyakarta, Juli 2005, 51-63.

[7] Suprapto, Sudjatmoko, T. Sujitno, Pengaruh Nitridasi Plasma terhadap Kekerasan AISI 304 dan Baja Karbon Rendah. Jurnal Iptek Nuklir Ganendra, Vol. 13, No. 2, 2010, 93-100.

[8] Sunarto, Metode Plasma Nitriding untuk Meningkatkan Kekerasan Pahat Bubut Potong Bahan Baja Kecepatan Tinggi (HSS) ASSAB 17, TEKNIS, Vol. 5, No. 1, 2010, 15-19.

[9] A. Azis, Pengaruh Perubahan Suhu Nitridasi Plasma Lucutan Pijar DC terhadap Kekerasan Baja AISI 4140, Thesis, Magister Teknik Mesin Sekolah Pascasarjana Universitas Muhammadiyah Surakarta, 2018.

[10] H. Pradana, Modifikasi Komposisi dan Struktur Mikro dengan Plasma Nitridasi Untuk Meningkatkan Kekerasan dan Ketahanan Aus Titanium Murni Komersial, Skripsi, Jurusan Teknik Mesin Fakultas Teknik Universitas Muhammadiyah Surakarta, 2018.

[12] U. Rumendi, H. Hermawan, Analisis Pengerasan Permukaan dan Struktur Mikro Baja AISI 1045 Melalui Proses Nitridasi Menggunakan Media Urea, Jurnal Konversi Energi Dan Manufaktur Universitas Negeri Jakarta, Vo. 2, April 2014, 104109. 